\title{
The Indonesian Coup September 1965: A Discussion from Bipolarity Structure
}

\author{
Mohd. Noor Mat Yazid ${ }^{1}$ \\ ${ }^{1}$ Programme of International Relations, School of Social Sciences, Universiti Malaysia Sabah, Kota Kinabalu, \\ Malaysia \\ Correspondence: Mohd. Noor Mat Yazid, Programme of International Relations, School of Social Sciences, \\ Universiti Malaysia Sabah, 88999 Kota Kinabalu, Malaysia. Tel: 6-012-868-0362. E-mail: \\ mohdnoory2011@yahoo.co.uk
}

Received: August 27, 2013 Accepted: January 9, 2014 Online Published: February 26, 2014

doi:10.5539/ass.v10n6p1 URL: http://dx.doi.org/10.5539/ass.v10n6p1

\begin{abstract}
This article discusses the Indonesian Coup 1965 from the bipolarity international political structure (Cold War). Power rivalry between the communist-socialist and democratic-capitalist during the Cold War period (bipolarity structure) had resulted the Indonesian Coup 1965. The 'new order' Indonesian administration emerged after the coup, replaced the 'old order' administration under President Sukarno. The different political philosophy and ideology of 'new order' under President Suharto shifted the Indonesian foreign policy from previously leaning against the East power to West power (democratic-capitalist). The domestic political changes after the Indonesian Coup 1965 contributed to the peaceful and harmonious relations with Malaysia and other capitalist state in the South East Asian region. The Indonesian 'new order' administration had paved the way to the formation of ASEAN in August 1967 and the creation of South East Asia regional stability.
\end{abstract}

Keywords: Indonesian Coup, bipolarity structure, new order, old order, regional organization, regional stability

\section{Introduction}

The Indonesian Coup of 1965 or GESTAPU (Gerakan tiga puluh September, or $30^{\text {th }}$ September Movement) was a significant event in politics and ideological changes in Indonesia. The event had transformed the politics of Indonesian from the 'old order' administration (under Sukarno with Communist influence) to the 'new order' administration under President Suharto and was pro-West government. Indonesian 'Gestapu' was also important because this event changed the regional political structure in Southeast Asian region and paved the way to the formation of strong regional organization, Association of South East Asian Nations (ASEAN). After the formation of ASEAN in August 1967, a new type of relationship between Malaysia-Indonesian and other pro-American countries in South East Asia (ASEAN members) began. There are two versions of Indonesian Coup 1965; the version I (the communist action) and version II (the Army and Pro-United States action). Both versions will be discussed in turn.

\section{Indonesian Coup 1965, Version I}

Communist Action: According to this version the Indonesian Coup of 1965 was a communist strategy to gain power in Indonesia. A few weeks before the 'Gestapu' event, President Sukarno's health was very poor. The communists took a prompt action before the army took power from President Sukarno.

On the midnight of $30^{\text {th }}$ September 1965 "progressive, revolutionary" military officers backed by the Communist (PKI) leadership, the so-called 'Gestapu,' (September $30^{\text {th }}$ Movement) were involved in the kidnapping and murder of six generals of the Indonesian army (Mahmud, 2000, pp. 212-213). General Suharto and Nasution who escaped death (Suharto not being on the priority list and Nasution being wounded) rallied opposition forces and put down the coup.

The objective of the 'Gestapu' had been to purge the army general staff and critics of the PKI and of President Sukarno. According to this version, if Suharto and Nasution had been killed on the $30^{\text {th }}$ September midnight, the coup might have succeeded and a communist regime might well have emerged in Indonesia (Fifield, 1973, p. 317).

General Suharto, with key figures Adam Malik, the Sultan of Jokjakarta and widespread student support, 
controlled the situation in early October 1965. Suharto was seen as a figure to control Indonesia from the communist coup. Without the role played by Suharto and the army, the PKI would control Indonesian politics. Indonesia would become a communist state after $30^{\text {th }}$ September 1965.

This version of the Indonesian coup of 1965 is totally different from version II (discussed below). Since the late 1980s and especially after the fall of President Suharto in 1998, many materials about the 1965 coup were published (and released) that gave more evidence to support version II of the Indonesian Coup 1965 (Scott, 1985, pp. 239-264).

\section{Indonesian Coup 1965, Version II: (The United States and Pro-West Action)}

According to this version, the United States and the Indonesian army were responsible for and played important role in the Indonesian coup of 1965 (Scott, 1985, pp. 239-264). The 1965 event was important in taking power from President Sukarno by the Indonesian army, led by General Suharto and was strongly supported by the American government. The communists in Indonesia (PKI) became much stronger after 1964 and much closer to President Sukarno. The army took the action because the possibility for the PKI leader to succeed President Sukarno was very great (if something happened to President Sukarno). Indonesia would become a communist state without the American and Indonesian anti-communist leader action on $30^{\text {th }}$ September 1965. Such a failure would render South East Asian region as one of the important 'communist sphere of influence.'

\section{Singapore Withdrawal from Malaysian Federation in August 1965: Impact to the Western Strategy and Relations to the Version II (The Possibility of Ejection of Sabah and Sarawak from Malaysian Federation)}

The ejection of Singapore from the Malaysian Federation in August 1965 made an upon impact the American decision in Indonesia in September 1965. President Sukarno argued that the ejection of Singapore in August 1965 would have destroyed the Federation of Malaysia from inside. It meant that after Singapore's ejection it would be followed by the other part of the federation. The most probable parts of the Federation of Malaysia to follow Singapore's decision were Sabah and Sarawak in Borneo Island (Kroef, 1965, p. 574). The political development in both parts of Malaysia (the political development in Sabah and Sarawak) in 1965 supported the logic of that argument. The majority of the population in Sabah and Sarawak were not Malays (native people in Sabah and Sarawak were different in certain aspect with the Malays in the Federation of Malaya). The Chinese and non-Malays were the majority population in the both states.

The American strategy and its decision on Indonesian on $30^{\text {th }}$ September 1965 affected the political development in Malaysia, especially the ejection of Singapore and would probably have been followed by Sabah and Sarawak. Sukarno's regime would support the ejection of Sabah and Sarawak from the Malaysian Federation (Mahmud, 2000, pp. 204-208). The Americans must control Indonesian government before the Federation of Malaysia was destroyed from inside. The situation would become more difficult for American strategy without pro-American government in Indonesia.

\section{Ideological Factor, Political Upheaval and the Changes in Political Relations}

The ideological is a vital factor in understanding the foreign policy and political relations of a state. During the Cold War period, this factor in certain situations became the most important and led to the other related factors. The ideological stance of a state will determine the position in the systemic structure. It is important in understanding the foreign relations and intra-state political relations. The changes of a domestic political ideology would contribute to the domestic political upheaval. The ideological political upheaval generally contributes to the changed pattern of foreign relations and political relations. The relationship and mutual impact of the ideological factor, domestic political upheaval, foreign policy decision and political relations can be seen clearly in the Indonesia and the Indonesia-Malaysia political relations in the second half of the 1960s. The changes in the Indonesian domestic politics after 1965 had influenced the Indonesian foreign policy. Indonesian bilateral relations with Malaysia and other pro-West countries in South East Asia improved dramatically after 1965.

\section{Indonesian Domestic Politics and Ideological Development after 1967}

Indonesian political development after 1967 was dominated by the new ideological rising in the Indonesian government. The event on $30^{\text {th }}$ September 1965 gave great chances for the democracy-capitalist military group to control Indonesian politics. The democracy-capitalist military group defeated the socialist-communist groups. In 1965 the Indonesia army was split into two camps. The first group was loyal to the army commander General Yani who was reluctant to challenge President Sukarno's policy of national unity in alliance with PKI. The second army group was the right wing who opposed General Yani's group and Sukarno's policies alliance with the communists (Crouch, 1978, pp. 79-80). The second group was anti-communist and pro-America led by 
General Nasution and Suharto. On 30 September 1965 General Yani and his inner circle of generals were murdered. Four of the six pro-General Yani leadership were killed on mid-night of $30^{\text {th }}$ September (Scott, 1985, p. 241). No-one of anti-President Sukarno's army group were killed and targeted by Gestapu, with the exception of General Nasution. General Nasution was able to escape, while his daughter was murdered on that night.

The $30^{\text {th }}$ September 1965 was significant in understanding Indonesian domestic politics and ideological development during the second half of 1960s. Gestapu was the struggle between the two ideological rivalries in Indonesia and in the Southeast Asian region. The author argued that the rivalries were not solely in Indonesia, but in the Southeast Asian region because PKI and Indonesia was the biggest country in Southeast Asia. PKI was the third largest communist party in the world in mid-1960s after Soviet Union and China. The struggle between the left (pro-general Yani, Sukarno and PKI) and the right (Suharto, capitalist and pro-America) was closely related with the regional and international political ideological struggle. It was significant in colouring the East Asian region.

The army anti-PKI played a vital role in the $30^{\text {th }}$ September Indonesian event. Without the army's anti-PKI propaganda the massacre might not have happened (Sundhaussen, 1982, p. 219). After 1965, the right wing group under Suharto played a significant role in Indonesian politics. The changes in ideological factors in Indonesian domestic politics influenced its foreign relations. Indonesian foreign policy was leaning to Western countries after 1965. The formation of political and economic spheres in Southeast Asia after 1965 was dominated by the changes of ideological factors in Indonesia.

The ideological factor played a significant role in Indonesian relations with Western countries after the 1965 coup. Indonesia terminated relations with communist countries and improved the relations with the Western countries. A bad economic situation in Indonesia in the early years after the coup was also an important task for the new regime to be improved. Suharto had to solve the economic catastrophe in the years after the coup to prove to the Indonesian mass that democracy-capitalist ideology was much better than the socialist-communist. Suharto needed confidence and support from the masses for his new regime. Western countries also had to assist Indonesia in consolidating the democracy-capitalist ideology strategy. The Tokyo Club (The United States, Japan, France, Great Britain, West Germany and The Netherlands), was formed after the coup by the West, with the main objective and strategy was to assist Indonesia's economic development. The Club was a further support from the Western countries towards Indonesia. Before the coup of 1965 event Western countries already gave their support to Suharto. The United States gave strong support to Suharto to overthrow Sukarno. Other Western countries such as Great Britain, West Germany, Japan and possibly Australia and New Zealand gave support to Suharto group. Based on the ideological factor West Germany assisted Suharto with delivering sub-machine guns, radio equipment and money of value of 300,000 marks (Scott, 1985, p. 45).

Ideological development in Indonesia after 1965 was a key factor in the changes in economic development, economic policies, foreign-policy decisions and political relations. Without the changes in the ideological factor, the changes in other aspects have been impossible.

\section{Ideological Factor and Indonesia-Malaysia Political Relations}

The ideological factor (Communist-socialist and democratic-capitalist) played a significant role in the Indonesia-Malaysia political relations. Communist-socialist ideology in the Indonesian regime under Suharto with PKI influence was the main factor in shaping the hostile relations during the period before 1966. The rising of pro-West support with democracy-capitalist ideology, influenced the harmonious relations between Indonesia and Malaysia after 1965. After 1966 Indonesia's military regime under Suharto was pro-West and followed the democracy-capitalist ideology. Indonesia entered a new economic and political sphere. i.e. Western sphere with capitalist economy and democratic politics. The confrontation with Malaysia was ceased in 1966. It was a first step in the Indonesian improved relations with democracy-capitalist sphere. The negotiation in Bangkok in 1966 and 1967 was the process of the consolidation of the capitalist group's position in Indonesia. The formation of ASEAN in August 1967 was the result of co-operation among the Southeast Asian capitalist states. Indonesia led the regional association (ASEAN). The strong support from Western countries, especially the United States, Great Britain and Japan contributed to the successful regional association.

The Indonesia-Malaysia political relationship after 1965 was a result of the changed ideological and political philosophy in Indonesia. The states that had a similar ideology, i.e. democracy-capitalist, tended to make good political relations. Regional security alliance also influenced the regional co-operation. Malaysia needed security protection under the British as a SEATO member. Indonesia needed security protection from inside and outside from the United States. The close Indonesian military partnership with America after the coup was clear. All of the ideology, security and economic advantages played a role in shaping the new political relations between 
Indonesia and Malaysia. The ideological factor led to the other factors in the early years after the Indonesian Coup of 1965.

\section{Ethnic Relations in Malaysia, Ideological Factors and May Thirteen 1969 Events in Malaysia: Impact upon Malaysia-Indonesia Relations}

Ethnic relations in Malaysia, especially the conflict between Malay and Chinese influenced the Malaysia-Indonesia political relations. One of the factors which contributed to the withdrawal of Singapore from Federation of Malaysia in 1965 was ethnic conflict, i.e. the differences between Malay and Chinese ethnic. The formation of DAP in Malaysia originated from the PAP political philosophy towards the Malays. The May 1969 general elections result on the West coast of Malaysia gave some confidence to the DAP and radical Chinese to control Malaysian politics. The aftermath of the 1969 general election was significant for the political and ethnic development in Malaysia. It led to the outbreak of an ethnic riot on $13^{\text {th }}$ May 1969. The riot was a very bad tragedy in ethnic relation and conflict in Malaysia.

The 13 May ethnic conflict in Malaysia gave a positive effect to the political relations between Indonesia and Malaysia. Malaysia and Indonesia were worried about the possibility of the communist party taking the opportunity to achieve their objective through the conflict. The Communist Party in Malaysia was greatly supported by the Chinese ethnic origin (The majority of the Malays was anti-communist). President Suharto of Indonesia offered military support to Malaysia over the issue to attack any possibility of communist rising after the May 13,1969 event.

\section{Conclusion}

This article discusses how important was the ideological factor and international political structure in shaping and influencing the Indonesian Coup of 1965 and Indonesia-Malaysia political relations during the period before and after 1965. The ideological factor had a close relationship with the systemic political rivalry and the domestic activities in Malaysia and Indonesia. The nature of diplomatic relations of both countries with democracy-capitalist and communist-socialist bloc was based upon the ideological factor. The changed foreign policy of Indonesia after 1965 (after the Indonesian Coup 1965) dominated the changes in ideological factors in Indonesian domestic political ideology. The pattern of the United States and Soviet Union involvement in Malaysia and Indonesian domestic politics dominated with international ideological factors. The ideological factor was one of the vital factors in understanding and analysing the Indonesian Coup 1965 and Indonesia-Malaysia political relationship during the period after 1965.

\section{References}

Bass, J. R. (1970, March). The PKI and the Attempted Coup. Journal of Southeast Asian Studies, 1.

Crouch, H. (1972). Military Politics under Indonesia's New Order. Pacific Affairs, 42(2), 206-219. http://dx.doi.org/10.2307/2755551

Crouch, H. (1978). The Army and Politics in Indonesia. Itacha, NY: Cornell University Press.

Dommen, A. J. (1966). The Attempted Coup in Indonesia. The China Quarterly, 25, 144-170. http://dx.doi.org/10.1017/S0305741000027831

Feith, H. (1964). President Sukarno, the Army and the Communists: The Triangle Changes Shape. Asian Survey, 6(8), 969-980. http://dx.doi.org/10.2307/2642634

Griswold, D. (n. d.). How Washington backed Bloodbath in Indonesia. Retrieved from http://www.hartford-hwp.com/archives/54b/032.html

Gunn, G. C. (1979). Ideology and the Concept of Government in the Indonesian New Order. Asian Survey, 19(8), 751-769. http://dx.doi.org/10.2307/2643719

Hilton, I. (n. d.). Our Bloody Coup in Indonesia. Retrieved from http://www.guardian.co.uk/Print/0,3858,4231700,00.html

Hindley, D. (1968). Indonesian Politics 1965-1967: The September Movement and the fall of Sukarno. The World Today, 24, 345-356.

Horn, R. C. (1971). Soviet-Indonesian Relations since 1965. Survey, 216-232.

Johnson, D. (1976). Gestapu: The CIA's "Track Two" in Indonesia. Retrieved from http://www.hartford-hwp.com/archives/54b/033.html

Kroef, J. M. V. D. (1960). Indonesia in the Cold War. Current History, 38, 88-94. 
Kroef, J. M. V. D. (1966). "Gestapu" in Indonesia. Orbis, 10(2), 458-487.

Kroef, J. M. V. D. (1969). New Political Patterns in Indonesia. The World Today, 25, 219-230.

Kroef, J. M. V. D. (1970-1971). Interpretations of the 1965 Indonesian Coup: A Review of the Literature. Pacific Affairs, XLIII(4), 557-577. http://dx.doi.org/10.2307/2754905

Kroef, J. M. V. D. (1970). Indonesian Communism since the 1965 Coup. Pacific Affairs, 34-60. http://dx.doi.org/10.2307/2753833

Leifer, M. (1965). Singapore Leaves Malaysia. The World Today, 21, 361-364.

Leifer, M. (1966). Indonesia and Malaysia: The Changing Face of Confrontation. World Today, 22(9), 395-405.

Leifer, M. (1967). The Process of Political Change in Indonesia. Royal Central Asian Journal, 54.

Liddle, W. R. (1985). Suharto's Indonesia: Personal Rule and Political Institution. Pacific Affairs, 58(1), 68-90. http://dx.doi.org/10.2307/2758010

Lucien, R. (1966). Dossier of the Indonesian Drama. New Left Review, 36.

MacDougall, J. J. (1976). The Technocrat Model of Modernization: The case of Indonesia's New Order. Asian Survey, 16(12), 1166-1183. http://dx.doi.org/10.2307/2643453

Mahajani, U. (1967). Indonesia's New Order and the Diplomacy of Aid. The Australian Outlook, 21(2), 214-234. http://dx.doi.org/10.1080/10357716708444276

Mahmud, N. A. N. (2000). Konfrontasi Indonesia-Malaysia (Indonesian-Malaysian Confrontation). Bangi: Penerbit Universiti Kebangsaan Malaysia.

Mas'oed, M. (1983). The Indonesian Economy and Political Structure during the Early New Order 1966-1971. Unpublished Ph.D dissertation, Ohio State University, Ohio.

Morfit, M. (1981). Pancasila: The Indonesian State Ideology According to the New Order Government. Asian Survey, 21(8), 838-851. http://dx.doi.org/10.2307/2643886

Mortimer, R. (1968). Indonesia: Emegre Post-Mortems on the PKI. The Australian Outlook, 22(2), 47-359.

Nadesan, A. (1979). Sino-Indonesian Relations (1950-1967) and Its Future? Indian Journal of Politics.

Notosusanto, N., \& Saleh, I. (1968). The Coup Attempt of the "September 30 Movement" in Indonesia. Jakarta: P.T. Pembimbing Masa.

Pauker, G. J. (1966). Communism in Indonesia. Problems of Communism, 15, 48-50.

Pauker, G. J. (1967). Indonesia: The Year of Transition. Asian Survey, 12(2), 138-150. http://dx.doi.org/10.2307/2642526

Pollard, V. K. (1971). South East Asian Regionalism. Journal of Contemporary Asia, 1(4), 45-54. http://dx.doi.org/10.1080/00472337185390181

Polomka, P. (1972). The Indonesian Army and Foreign Policy: A Reappraisal. Asia Quarterly, 4(4), 363-382.

Quiko, E. (1970). The Role of Foreign Minister Subandrio in Indonesian Politics: Analysis of Selected Indonesian Foreign Policies, 1957-1965. Ph.D dissertation, Department of Government, Southern Illinois University, July 1970.

Ra'anan, U. (1966). The Coup That Failed: A Background Analysis. Problems of Communism, 14(2), 37-43.

Rey, L. (1966). Dossier of the Indonesian Drama. New Left Review, 36, 26-40.

Scott, P. D. (1985). The United States and Overthrow of Sukarno, 1965-1967. Pacific Affairs, 58(2), 239-264. http://dx.doi.org/10.2307/2758262

Subritzky, J. A. (2000). Britain, Konfrontasi, and the End of Empire in Southeast Asia, 1961-1965. The Journal of Imperial and Commonwealth History, 28(3), 209-227. http://dx.doi.org/10.1080/03086530008583106

Suchahyo. (1967). The New Order in Indonesia. World Marxist Review, 46-48.

Sullivan, J. H. (1969). The United States and the "New Order" in Indonesia. Ph.D dissertation, School of International Service, The American University, Washington D.C. 1969.

Sundhaussen, U. (1982). The Road to Power: Indonesian Military Politics, 1945-1967. Kuala Lumpur: Oxford University Press.

Vincent, K. P. (1970). ASA and ASEAN, 1961-1967: Southeast Asian Regionalism. Asian Survey, 10, 244-255. 
http://dx.doi.org/10.2307/2642577

Weatherbee, D. J. (1970). Interpretation of Gestapu, the 1965 Indonesian Coup. World Affairs, 312-320.

Wertheim, W. F. (1966). Indonesia before and after the Untung Coup. Pacific Affairs, 39.

Wertheim, W. F. (1970). Suharto and the Untung Coup-the missing link. Journal of Contemporary Asia, 1(2), 50-57. http://dx.doi.org/10.1080/00472337085390151

Wertheim, W. F. (1979). Whose Plot? New Light on the 1965 Events. Journal of Contemporary Asia, 9(2), 197-215. http://dx.doi.org/10.1080/00472337985390191

Yazid, M. N. (2000). Ideological and Territorial Factors in the Indonesia-Malaysia Confrontation 1963-1966. Asian Profile, 28(4), 303-306.

\section{Copyrights}

Copyright for this article is retained by the author(s), with first publication rights granted to the journal.

This is an open-access article distributed under the terms and conditions of the Creative Commons Attribution license (http://creativecommons.org/licenses/by/3.0/). 